\title{
Învățătură pentru ferirea și doftoria boalelor (1816). Considerații asupra gloselor
}

\author{
Liliana Soare* \\ Facultatea de Litere, Universitatea din Pitești, Str. Gh. Doja 41, 110253 Pitești, România
}

\section{Despre articol \\ Istoric:}

Primit 11 aprilie 2014

Acceptat 26 mai 2014

Publicat 13 ianuarie 2015

Cuvinte-cheie:

glose

integrarea împrumuturilor

modernizarea limbii literare

\begin{abstract}
Rezumat
Scopul prezentei lucrări îl reprezintă analiza gloselor excerptate din Învățătură pentru ferirea și doftoria boalelor, text tradus de Petru Maior și tipărit la Buda, în 1816. Principiul iluminist după care se ghidează învățatul ardelean, de adaptare a culturii occidentale la cultura română, de facilitare a accesului maselor populare la știință se concretizează în frecvența ridicată a gloselor. Pentru cărturarul ardelean, glosa reprezintă un excelent mecanism de inserție în text a neologismelor, care sînt explicate prin cuvinte vechi, populare, sintagme ori perifraze. Ponderea cea mai însemnată o ocupă glosele terminologice, de tipul imprumut lexical - cuvînt vechi. Acest fapt este relevant pentru concepția care îl călăuzește pe autor în activitatea de traducere a textului: glosele sînt orientate intențional spre crearea unui fond lexical neologic, în deplin acord cu cel al limbilor europene de cultură. O examinare detaliată a variatelor tipuri de glose oferă informații utile în ceea ce privește fenomenul de integrare a neologismelor și revelează aspecte interesante ale procesului de înnoire lexicală a limbii române literare.
\end{abstract}

\section{Preliminarii}

1.1. Petru Maior desfășoară o impresionantă activitate de traducere, adaptare și elaborare a numeroase texte din varii domenii; activitatea sa editorială ne revelează o operă organizată pe aproape toate fronturile iluminismului românesc, operă care jalonează cele mai importante domenii ale culturii scrise din epocă. Ca cenzor al tipografiei budane, lui Petru Maior îi revine, printre alte obligații de serviciu, și sarcina de a traduce cîteva texte de popularizare a științei pe care nu le semnează ca traducător. Ursu (1961) conchide, întemeindu-se pe convingătoare argumente lingvistice, că și acest text de medicină veterinară, cu titlul complet Învățătură pentru ferirea și doftoria boalelor celor ce se încing prin țeară și a celor ce se leagă și a unor boale sporadice, adecăpe ici pe colo imblătoare, ale vitelor celor cu coarne, precum și a cailor, a oilor și a porcilor (130 de pagini), apărut la Buda, în 1816, este o traducere aparținînd lui P. Maior ${ }^{1}$.

1.2. Cele mai multe texte de popularizare a științei care apar în această perioadă în Transilvania sînt traduceri şi adaptări după originale latine, germane sau maghiare, scrieri utilitare circumscrise literaturii de stat, oficiale, cu circulație în toate spațiile culturale ale imperiului. Traducerea acestora era o sarcină a tipografiei budane, care avea să fie dusă la îndeplinire cu ajutorul revizorilor cărților românești. Ca și tipografia românească din Viena sau Liov, tipografia din Buda era obligată, date fiind coordonatele politicii culturale a imperiului austriac, să tipărească manuale școlare și texte de popularizare pentru românii ardeleni. Finalitatea acestora este variată, ceea ce subliniază intenția de culturalizare a maselor, prin trecerea de la o literatură „savantă” la una orientată spre nevoile stringente ale comunităţii. Multe sînt „învățături”, care își arată încă din titlu destinația: Invvățătură pentru ferirea și doftoria boalelor, Învățătură pentru prăsirea pomilor, Învățătură despre cultura și creșterea frăgarilor, Învățătură de a face sirup și zăhar,

*Adresă de corespondență: lilianasoare2006@yahoo.com.

${ }^{1}$ Pentru alte traduceri inedite ale cărturarului ardelean, v. Ursu (2012). 
Învățătură firească spre surparea superștiției norodului etc., altele „povățuiri”: Povățtuire cătră economia de cîmp, Povățiirea cu praxis cătră sporirea stupilor etc., scrieri cu o certă orientare pedagogică.

Asimilarea masivă a textelor străine „dezvăluie, incontestabil, un proces de înnoire a unei scheme culturale și o mai bună înțelegere a acestuia presupune, în primul rînd, integrarea activității de traducere în ansamblul dezvoltării culturii scrise și, în al doilea rînd, investigarea literaturii ca formă de expresie a structurilor mentale din societatea română” (Duțu, 1970, p. 155). Activitatea de traducere și adaptare a operelor străine nu înseamnă doar sincronizarea literaturii și a culturii române cu cea occidentală, ci reprezintă și asimilarea unei noi mentalități despre om, ce se concretizează într-o literatură de interes general, accesibilă. Preluările din această perioadă au la bază o schimbare profundă a structurilor mentalitare și o mutație în rîndul cărturarilor, mult mai deschiși către o literatură utilitară, de masă, care să fie introdusă într-un circuit mult mai larg.

După cum s-a observat (Prodan, 1964, p. 5), traducerea în această perioadă nu reprezintă o transpunere comodă, dintr-o limbă în alta, de noțiuni cunoscute într-un limbaj științific deja constituit. Traducerea este ea însăși o creație, punînd traducătorului probleme mai dificile decît scrisul original într-un limbaj care-i este familiar. În perioada în care-și desfăşoară activitatea cărturarii ardeleni, individualitatea și originalitatea nu reprezintă trăsături pertinente în definirea operei. Învățații transilvăneni modifică, recreează, stilizează textul pe care-l traduc; introduc comentarii, elimină informații, înlocuiesc exemplele cu altele familiare cititorului român, conectează fragmente din surse diferite, prefațează lucrările.

Însă, în cazul textelor oficiale, elaborate pentru toate popoarele Imperiului, traducătorii nu adaptează textul, ci, de regulă, îl redau cu fidelitate. Fidelitatea limbii traducerilor primează, însă la fel de importantă este și strădania autorilor de a respecta firea limbii române. Maior (1813), de exemplu, condamnă acuratețea artificială, forțată a limbii în care se traduce, arătînd că: „Grecii așa vreu, ca cărțile cele besericești [...], cînd se întorc pre altă limbă, așa să se întoarcă, cît nu numai înțălesul cel cuprins în cărțile acele să se țină, ci și țesetura cea din lontru a limbei grecești” (p. 182). Prin urmare, cărturarul pledează atît pentru păstrarea exactităţii ideilor și a sensurilor cuvintelor, cît și pentru menținerea specificului limbii: „Românii [...] cărţile cele besericești le-au întors pre românie după firea limbei românești, numai de aceea grijindu-se ca înțălesul să rămînă întreg” (p. 183). Avînd în vedere că teoria traducerii nu se constituise încă, concepția este de o frapantă modernitate.

1.3. Se pare că textul este tradus după un original maghiar, rămas, deocamdată, neidentificat, fapt care face imposibilă confruntarea celor două texte. Ideea originalului maghiar este susținută de faptul că, în două cazuri, apar expresiile „iubita noastră patrie Ungaria” și „patria noastră Ungaria”: „Întră toate lîngorile sau boalele cornutelor adecă vitelor celor cu coarne, foarte adeseori, cu nenorocita și prea contăgioasa boala de vite sau puștla cornutelor, iubita noastră patrie Ungaria se devastă adecă se pustiaște, cît însuși cei mai puternici moștenitori ale largilor moșii nevindecate pagube pentru pierderea vitelor sale sînt strimtorați a simți, iară țăreanii ce sînt supuși dărei nu arareori la cea de pre urmă lipsă ajung” (22-23); „Iară cum că boala de vite în patria noastră Ungaria adeseori se escază (și se escază pentru locurile țărei pe ici, pe colo apuse, aşezate, pentru unele locuri băltoase, pentru desele vărsări de ape, pentru răsfugările pămîntului cele cu putrăgiune, pentru notrețul cel stricat, pentru aerul cel nesănătos, pentru apele cele tăioase), care toate, afară de contagiu, cum că singure de sine pot să nască această pierzătoare boală, netăgăduit lucru iaste” (25). Într-un alt loc, Moldova și Țara Românească sînt considerate „țări streine”: „Întru adevăr, de prisosit iaste acum adeverit, cum că boala cea de vite și în țeara noastră mai adeseori se urzește: totuş, cum că acest stricătoriu rău mai vîrtos din țări streine, precum Moldova, Țeara Românească, Rusia se lățește la noi, dovedit iaste" $(28-29)^{2}$.

1.4. După cum observa Ursu (1962, p. 61), aceasta este prima scriere medicală în care întîlnim o terminologie de specialitate mai bogată, cu un pregnant caracter neologic. Ceea ce frapează însă, pe lîngă numărul mare de împrumuturi ${ }^{3}$, este frecvența extrem de ridicată a gloselor (de altfel, titlul însuși conține

\footnotetext{
${ }^{2}$ Aceste fragmente sînt o dovadă în plus că Maior urmărește îndeaproape originalul: autorul maghiar vorbește despre „patria noastră Ungaria”, iar referirile la celelalte două provincii românești ca țări străine sînt făcute din exterior.

${ }^{3}$ Vom dedica împumuturilor lexicale un studiu special; la o consultare rapidă a principalelor noastre lucrări lexicografice,
} 
o astfel de structură explicativă: boale sporadice adecă pe ici pe colo îmblătoare). Termenii neologici sînt glosați la fiecare utilizare, rare fiind cazurile în care aceștia apar, ulterior primei lor glosări, neîncadrați în aceleași sau noi structuri explicative. O pagină obișnuită a cărții se prezintă, în general, ca în următoarele exemple: „Aftele sau răniturile limbei trăbuie să se socotească numai ca simptome adecă schimbări fără cumpăt sau depunerea, descărcarea materiei ceii morboasă adecă a morbului sau a boalei la zisele părți; pentru aceea periclu sau rișchiu adecă primejdia boalei depende (atîrnă) de la forța adecă puterea ziselor friguri” (74); „Grumăzarea sau angina sau brînca porcilor iaste epidemică adecă se încinge și e foarte fatală sau stricătoare boală” (81).

Aflîndu-se în fața unor concepte (științifice) noi, cărturarul ardelean este constrîns să apeleze la asemenea procedee de explicare, pentru a facilita înțelegerea și însuşirea lor. Vulgarizarea științifică, care are ca obiectiv adaptarea textului științific pentru a putea fi receptat de publicul obişnuit, se combină cu vulgarizarea lexicală, care ține cont de nivelul cultural al publicului căruia i se adresează, informațiile fiind formulate, prin urmare, în sistemele lingvistice de reprezentare ale destinatarului. De altfel, în postfața lucrării, P. Maior, perfect conștient de faptul că noile cunoștințe, pentru a fi înțelese, trebuie traduse în idiolectul destinatarului, îl avertizează și îl îndrumă pe acesta în călătoria spre edificarea sensului cărții: „Cinstite cetitoriule! Vei afla unele cuvinte în cărticica aceasta, care, poate cu văzuta dintîiu, nu le vei pricepe; ci să nu te scăndălizești! [...] Deci să binevoiești a ceti și a prociti toată cărticica, că toate acele cuvinte, care ți se părea streine, au într-un loc, au într-altul, au încă mai de multe ori le vei afla cu cuvinte de ale patriei tale tălmăcite și la dezvălită înțelegere aduse” (127, subl. n.).

Deși impresionantă, această obsesie a accesibilităţii încarcă uneori textul și afectează cursivitatea frazei: „Semne de moarte sînt pulsu sau mișcarea, baterea sîngelui mai nepriceput, cu atîta celeritate (pripire, iuțeală) zbucnește, cît aproape la o sută, ci cu oscuritate, adecă întunecat, se numără, respirația sau răsuflarea e scurtă, sufocativă, adecă sugrumătoare, apetita prostrată sau depusă, pierdută, aversația, adecă urîrea apei; unde ocură (vin, se ivesc, se văd) aceste semne, nu va trăi animantul o jumătate de zi, iară acele adeverit amuș vor subsi, a cărora urechile și astremitatele acum le sînt răci, cărora, de li băga degetele în urechi, nici capu nu-și mișcă” (63-64).

1.5. Ca procedeu lingvistic ce constă în stabilirea unei relații de echivalență între doi termeni (lexematici sau sintagmatici) sau în explicarea, prin intermediul perifrazelor, a unor cuvinte, glosarea lexicală se întîlnește încă din primele noastre texte elaborate în secolul al XVI-lea. Fenomenul glosării se manifestă cu o forță extraordinară şi cu un scop bine determinat la sfirșitul secolului al XVIII-lea și începutul secolului al XIX-lea, cînd se formează româna literară modernă și cînd se ridică problema creării terminologiei științifice și a difuzării ei în rîndul maselor. Glosarea asigură precizia și funcția denotativă a limbajului științific. Totodată, acest mecanism lingvistic este relevant pentru intenția de accesibilizare a noilor termeni, dar și pentru raportul dintre terminologia savantă și cea de tip tradițional, surprinzînd integrarea lexicală şi semantică a neologismelor. Glosele constituie, așadar, un factor important de pătrundere și punere în circulație a neologismelor, pregătind terenul semantico-stilistic pentru înnoirea limbii literare.

Literatura de specialitate înregistrează mai multe studii asupra gloselor din vechile texte românești ${ }^{4}$. Spre deosebire de ceilalți cercetători care s-au aplecat asupra problemei, Al. Gafton privește procedeul ca pe o componentă organică a activității de traducere, ca factor creator de normă literară; prin urmare, cercetătorul ieșean examinează glosele din vechile noastre texte (religioase) din perspectiva nevoilor care le-au generat și a funcțiilor pe care le îndeplinesc. Gafton (2012) propune și o tipologie de bază a gloselor,

am remarcat faptul că multe dintre neologismele care-și găsesc în acest text probabil prima lor atestare în limba română sînt datate ulterior ori nu sint consemnate.

${ }^{4}$ Dintre acestea, amintim doar cîteva: Gh. Şincai. Opere, vol. 1, București, 1967, ediție (în patru volume) realizată de F. Fugariu, care, în studiul introductiv, excerptează și interpretează un material foarte bogat de glose (p. CLXXIX-CLXXXVII); G. Țepelea, Studii de istorie și limbă literară, București, 1970 (p. 13-51); Al. Niculescu, Premesse sul problema dei rapporti cultural-linguistici italo-romeni, în „Actele celui de-al XII-lea Congres internațional de lingvistică și filologie romanică”, II, 1971, p. 893-904; Niculescu (1978, p. 148-158); E. Toma, Limbajul științific românesc la începutul epocii moderne (secolele XVIII-XIX), București, 2003 (p. 172-183); L. Soare, Școala Ardeleană. Lexicul scrierilor de popularizare a științei, Pitești, 2012 (p. 168-177). 
vorbind despre glosele explicative, glosele completive și glosele orientative. Multe dintre acestea, arată autorul, pot întruni caracteristicile tuturor tipurilor de glose, de aceea o tipologizare prea riguros concepută este aproape imposibilă (p. 323-358).

\section{Inventarul gloselor}

Majoritatea gloselor întîlnite în textul Învăţăturii pentru ferirea și doftoria boalelor sînt explicabile prin indigența limbii române a perioadei, care nu deținea termenii necesari pentru a denumi noile realităţi. Cele mai numeroase sînt cele care explică termenii noi, necunoscuți sau puțin cunoscuți cititorului, în termeni de limbă populară.

2.1. Din punct de vedere grafic, acestea apar integrate în text. Se întîlnesc însă și 13 situații în care glosele sînt plasate în subsolul paginii. Acest tip de glosare este relevant pentru momentul de început al dezvoltării aparatului critic, al elaborării științifice a textelor după norme specifice:

- Despre ferirea boalei vitelor, g. „Vită iaste orice are sîmţire și răsuflare. Deci cu acest nume numim preste tot boii, caii, oile, caprele, porcii ș.c. Și la latini au trăbuit mai demult aceste să se cheame vite; și de acolo au rămas la latini cuvîntul veterinaria (v e t e r i n a r i a), adecă măiestria de a doftori vitele. Vita se zice românește și viețuitoriu, ba și animant și animal, care nume se cuvine și omului, numai că omul iaste animal cuvîntătoriu, iară vita e animal necuvîntătoriu." (3);

- notreț, g. „Notrețiaste fînul, paiele, ovesul și orice cu care se hrănesc vitele. Cuvîntul acest iaste născut de la vorba latinească nutrio (n u t r i o), care va să zică „hrănesc”. De acolo zicem nutremînt, carea aceea înseamnă ce și cuvintul, notreț: nutresc, carea una e cu hrănesc." (3);

- poiețile sau staurile, g. „Sălașelor, unde se ține închise și se hrănesc vitele, pre alocurea după feliurile vitelor desclinite nume s-au obicinuit a se da, așa: sălașul unde se țin vitele cele cu coarne, adecă boii, vacile, îl cheamă poiată, unde caii, grajd, unde oile, staur, unde porcii, coteț sau cocină ș.c. Noi a tuturor vitelor, ori de ce plasă să fie, sălașul îl chemăm în cartea acesta staur, că şi latinii toate acestea le numesc stabula, de unde vine și cuvîntul românesc, staur." (4);

- comunitatelor, g. „Comunitate se zic toți oamenii laolaltă socotiți, cîți sînt în sat sau la oraș. Uneori comunitatea cea mare se împarte în mai multe parțiale sau mai mici comunități. Așa, în Peșta iaste comunitatea românilor, comunitatea grecilor, comunitatea sîrbilor ș.c." (5);

- copia, g. „Vitele toate laolaltă ce sînt supt căștiga, adecă grija păstoriului, unii după plasa vitelor le dau desclinite numiri; aşa, zic turmă de oi, iară turmă de boi nu zic. Noi toate le chemăm copia, după datina românilor celor preste Dunăre, care cuvînt în sine înseamnă mulțime." $(6)^{5}$;

- contagiu, g. „Contagiu se zice acel feliu de boală de carea, numai de se va atinge cel cu această boală de cel sănătos, cel sănătos încă se împle sau boala carea cu atingerea se leagă de altul, cum e vărsatu, rîia ș.c. Deci boale contăgioase se zic acele care cu atingerea se leagă de alții." (11-12);

- lîngori, g. „Lîngoare, pre alocurea, se numește numai un feliu de boală rea, de carea doarme omul dus și, ieșindu-și din fire, vorbește într-aiurea. Ci, fiindcă acest cuvînt în sine înseamnă orice plasă de boală la românii cei preste Dunăre, și noi în cărticica aceasta întru acel înțăles îl luăm, adecă pentru orice beteșug; totoş, uneori însămnăm cu el anume boala cea rea." (12);

- epizootice, g. „Epizootică boală iaste carea se întinde și se încinge mai preste mult loc întră vite fără de a se împlea una de alta. Însă sînt unele boale, care, afară de aceea că sînt epizootice, au și contagiul împreunat." (13);

- călbeaza, g. „Călbeaza latinește se cheamă Fasciola hepatica, adecă „fașă de ficat”; Carbasus asemenea la latini e o pînză de in foarte subțire, carbasus, dară nu e departe cu înțălesul de „faşă”, deoarăce și carbasul

\footnotetext{
${ }^{5}$ Potrivit concepției sale că limba română literară trebuie îmbogățită și cu împrumuturi din aromână — în postfața traducerii, Maior afirmă: „...întru prefacerea aceștei cărticică m-am întrebuințat cu mai multe dialecte ale limbei românești, din carele unele nu sînt astăzi cunoscute în patria ta...” (127) —, P. Maior folosește și cîteva cuvinte din acest dialect: căștiga "grijă” (6), copie „mulțime, turmă” (6), demînda „porunci” (29), puştlă „ciumă, pestă” (22). Tot pe seama influenței dialectului macedoromân poate fi pusă și prezența formelor cu a protetic, precum: acășsună, acrescută, adoi, adoită, amişcată, arîde, aroade, asparge, atoarnă etc., care se întîlnesc în multe dintre traducerile sale.
} 
slujește la înfășare. Pentru aceea mi se pare că cuvîntul nostru călbează e născut din latinescul carbasus, mutînd $r$ în $l$, de nu vei vrea mai bucuros a-l trage de la collabasco, fiindcă vitele care au călbează sînt de căzut, de perit; sau de la calvesco, carea înseamnă „mă pleșugesc”, pentru că turma în care încape călbeaza foarte se pleșugește, adecă se rărește, cît de multe ori nici o oaie nu rămîne în viață din turma aceea." (15-16);

- boala de vite, g. „Precum cuvîntul lîngoare pre alocurea înseamnă numai un feliu de boală rea ce vine pe oameni, așa cuvintul boală de vite înseamnă acea boală rea ce vine pe vitele cele cu coarne, carea la latini se numește Lues Omasi, adecă boala mațului celui cărnos, și iaste ca o puștlă, adecă ciumă întră cornute. Întru acest înţeles luăm și noi aci cuvîntul acela.” (22);

- dosă, g. „Dosa, latinește dosis, e cuvînt doftoresc, carele înseamnă acea măsură de lucruri cîtă se dă deodată ori la om, ori la vită." (47);

- gangrenă, g. „Gangrena e carne moartă carea se naște din rană sau din înflămație (aprindere, obrintitură), căria, de nu-i vei sta în coantră cu timpurie vindecare, se tîrîie mai încolo și tot merge înainte rozînd carnea." (57);

- boala cea mucoasă sau suporința, g. "Suporința se zice de la cuvîntul latinesc suppurațio (s u p p u r a t i o), pentru că materia carea iase în boala aceasta din nările calului iaste în chipul puroiului." (85).

Exemplele excerptate învederează caracterul complex al acestor structuri explicative, nu de puține ori autorul folosindu-se de procedeul „glosei în glosă”. Acest tip de glose oferă ample explicații ale cuvintelor, dar și indicații etimologice cu scopul de a facilita înțelegerea noilor cuvinte. Cîteva dintre acestea „trădează” preocupările lingvistice ale lui P. Maior, cum ar fi cîmpul lexical stabilit în cazul glosării lui poiată sau situația cuvîntului călbează, care beneficiază, prin implicarea directă a traducătorului: pentru aceea mi separe că, de explicații lingvistice foarte detaliate făcute cu scopul orientării cititorului și al lărgirii orizontului de cunoaştere al acestuia. Punctul de plecare al acestor glose de subsol îl constituie „un segment de text, pretext pentru ca receptorului să i se furnizeze informații noi, care-i lărgesc orizontul sapiențial și de gîndire” (Gafton, 2012, p. 356). Dincolo de „rolul lămuritor și îmbogățitor”, aceste glose au rolul „de a atrage cititorul spre text, de a-l instrui și forma în sensul și pe baza textului [...]" (ibidem).

2.2. Glosele care apar încadrate în text sînt cele mai frecvente. Acestea învederează diverse tehnici de glosare, prin folosirea parantezelor, a juxtapunerii, a conjuncției sau ori a apozemului explicativ adecă.

2.2.1. Un prim tip de glose, cele mai frecvente, încorporează sinonime (lexeme sau sintagme) din lexicul comun în structuri:

a) binare: se va acerăla (sic!) adecă pripi ,accelera” (125), acrimonia sau ascuţimea (100), acurata (cu de ajuns) (48), cu afte adecă cu beșicuțe (72), aftele sau răniturile limbei (74), vor alăbora adecă vor lucra (44), amputația adecă tăierea (111), angina sau grumăzarea porcilor (82), animal (viețitoriu) (62), antifloghistice adecă asupra fierbințelii (51), ample (largi) (65), apetita adecă voia de a mînca (55), apetita adecă voia de mîncare (69), de argilă adecă de lut (80), aversația, adecă urîrea (63), aversă adecă urește (101), boala cea mucoasă sau suporința (85), cadabru adecă trupul cel mort (45), a cadabrului adecă a trupului celui mort (37), putoarea cea cadăbroasă sau de mortăciune (71), calce (var nestins) (114), castrația adecă jugănirea (111), causa sau pricina (73), cautele adecă feriri (33), cauterisaţia adecă arsura (111), cauteriu adecă fier ars (51), cauție sau ferire (89), cădabru adecă mortul al ei trup (32), (lipsit de) cerc (roșu), adecă de imprejurare (roşie) (56), cicatrice adecă urmă de rană (121), circulația adecă îmblarea sîngelui (124), circumciderea adecă tăierea împrejur (111), a clăudica adecă a schiopăta „claudica” (92), coloră adecă față (56), comerciul adecă împărtășirea cu vite (35), să se comită adecă să se încredințeze (116), boală complicată adecă îndoită (82), comuna (de obște) păşune (31), (sub pedeapsa) confiscației (contraband) (43), contaminate adecă spurcate (91), de a se contăgi adecă de a se împlea (de la alte oi de această boală) (58), continue adecă necurmate (81), să se continue adecă să nu se curme (84), să o continue adecă să nu o curme (122), contrarii adecă improtivitoare rînduieli (22), cornute adecă vite cu coarne (18), notrețul corupt adecă stricat (94), coruptul adecă stricatul (62), cremotartariu adecă piatră de vin (67), cristalin adecă ca cristalul (57), cruderă adecă nemilostivă (125), cruderitate adecă tirănie (125), custode (păzitoriu) (39), custodie (pază) (39), damne adecă pagube (110), decoct adecă zeamă fiartă (51, 
61, 123), decoctu (zeamă fiartă) (76), să se defalce, adecă să se cosască (9), a se dedura (gilui) ${ }^{6}$ (91), deliriul adecă nebunia (84), denudata adecă despoiata piele (99), depende (atîrnă) (74), plămînile depravate adecă stricate (82), depunerea, descărcarea materiei ceii morboasă (74), destinatul adecă rînduitul loc (45), să se dețină adecă să se oprească acasă (66), se devastă adecă se pustiaşte (23), devăgînd, adecă îmblînd ermii sau pustii pre platei (ulițe) (107), se devide sau se imparte $(73,77)$, a devora adecă a mînca (108), diarea adecă cufurirea (26), diarea adecă cufureala (51), diferență (desclinire) (113), se diferesc (se deosebesc) (55), să nu se dimită (sloboadă) la păşune (66), regulele cele diretive adecă îndreptătoare (21), dirigență (sîrguință) (108), disposiții adecă rînduieli (114), disposiții sau rînduieli (104), disposiţiiile (rînduielile) (38), distanță (depărtare) (34), diversă sau deosebită (natură) (55), diverse adecă deosebite (19), doftor sau hirurg (119), emeticu tare (leac de borît) (84), epidemică adecă se incinge (81), esculente adecă bucate putrăde „excremente?” (108), esempruri adecă pilde (111), faciritate adecă cu lesnire (87), falsă adecă neadevărată (95), fatală sau stricătoare boală (81), fatalul adecă pierzătoriul (34), fenomene (arătări) (83), fluid adecă curătoriu (117), cu foarcepă adecă cu clește (115), forța adecă puterea (74), cu forța (sila) (39), cu fosă adecă cu groapă încungiurate (41), apă frigidă adecă rece (84), frigidă (rece) (108), funestul adecă perzătoriul rău (105), furfură adecă tărîțe (cu apă stropite) (60), de furfură adecă de tărîțe (fierte) (61), găngrenos adecă rănit (27), generale (pe de asupra) (21), spre generație adecă spre prăsire (95), genuin (adevărat) (96), în gradu adecă în treapta (86), bronice adecă lung vecuitoare (86), infusu sau fiertură (122), înferma adecă bolnava vită (80), înflamația sau aprinderea (77), rane înflämate sau aprinse (72), înflämația sau aprinderea (61), înfus a decă zamă fiartă (69), să se înhume adecă să se îngroape (114, 115), se va înstila adecăpicura (54), să se întărzică (oprească) (44), lienita sau boala de splină (62), (cu) lienitidă adecă cu boală de splină (57), litarghiriu adecă de oțet de spumă de argint (79), masă adecă aluat (69), membrana sau peliţa (88), moment (cirtă) (125), morbul adecă boala (68), morbu sau boala (81), mordac adecă muşcătoriu (110), moturi (mişcări) (123), munde adecă curate (64), munde adecă curățite (85), murii adecă păreții cei de pietră (53), murii sau păreții cei de pietră (91), necesarie (de trăbuință) (116), necesitatea adecă lipsa (49), necesitați sau strimtorați (108), necorupt adecă nestricat (108), nocib sau vătămători (109), nocibe adecă vătămătoare (107), nocivă adecă vătămătoare (71), partea cea nudă adecă goală (93), nude adecă goale (71, 115), nutremînt (notreț) (50), de nutremînt adecă de hrană (108), nutri adecă brăni (90), ocasia (prilejul) (111), ocasionale adecă prilegiuitoare (105), oculația adecă altuirea vărsatului (59), operații (lucrări) (110), o oră adecă un ceas (34), cu oscuritate, adecă întunecat (63), a se osărba (a se ținea) (107), se oserbă adecă să ia aminte (101), ostipația adecă încuiarea pîntecelui (66), ostruție adecă incuiere (67), palatul adecă ceriul gurei (72), pastă adecă aluat (80), penuria adecă lipsa (62), peregrinatori (nemernici) (39), în periodul adecă în cursul (87), de precauție adecă de încungiurare regule (107), predespun adecă gătesc spre această boală (89), preserba adecă scuti (112), preservativ sau scutitoriu asupra pierzătoarei boală (48), mijlociri preservative și curative adecă apărătoare și doftoritoare (21), preservativă sau apărare (48), preservative sau apărări (111), prescriptul sau rînduitul modru (32), prescripții (rînduieli) (53), producturile (rodurile) (39), produturi sau lucruri (19), profondă adecă a dîncă (63), promove (miscă) (65), impedecarea propagației adecă a lățirei (105), proporționate (potrivite) (65), propria (a sa) (42), proprietari adecă stăpîn (31), să se proveadă adecă să se grijească (38), prudent (cu înțelepție) (95), pruringine adecă mîncătură scărpinătoare (92), prurit adecă mîncătură scărpinătoare (92), prurit adecă mîncare cu scărpinare (121), pulsu sau baterea sîngelui (68), răsfugările sau răsuflările (pămîntului) (6), să se răpurge adecă să se curăță $(53,109)$, î răsistă adecă îi stă în coantră (65), remediu (leac) (112), remediuri (lecuri) (67), loc remotu adecă depărtat (32, 46), repurgația adecă curățirea (52), respirația adecă răsuflarea (63), roborîtoare adecă întăritoare de stomah (de rînză) „roborant, medicament cu acțiune tonică” (69), mai robuste adecă mai tari (62), sapidă (plăcută) (95), săturat adecă bine fiert „saturat” (84, 85), scabia adecă rîia (94), causa scabiei adecă a rîiei (94), să se scarifacă adecă lin să se străpungă (120), rane scăbioase

${ }^{6}[$...] „,celelalte ale staurului vase de lemn cu muc contaminate adecă spurcate bine se cade a se dedura (gilui), cu dorabla a se netezi” [...] (,a gelui”, ,a rindela”).

${ }^{7}$ „Emanație, evaporare, transpirație”. Cuciureanu (1959, p. 56) îl explică prin it. sfogare (din exemple precum sfogare la passione), care înseamnă ,a-și descărca, revărsa patima”. 
adecă rîioase (93), schiroasa adecă vîrtoasa îmflătură (86), segregată adecă despărțită de cealelalte (33), segură adecă fără primejdie (112), separată adecă despărțită (31), loc separat sau despărțit (32), servitorii (slujitorii) (44), siguranța (neprimejduirea) (41), simplă (nu lucrată) (60), simptome adecă schimbări färă cumpăt (74), simptomele sau schimbările cele färă cumpăt ale morbului adecă a boalei (68), simptomele sau schimbările cele necumpătate ale boalei (101), spera (nădăjdui) (88), a se spera adecă a se nădăjdui (74), speranță adecă nădejde (83), sperare adecă nădejde (125), speriință sau ispita „experiență” (24, 82), spese sau cheltuiele (89), grija speselor adecă a cheltuielelor (32), spise adecă groase (73), boale sporadice, adecă pe ici pe colo îmblătoare (f.t.), cu strie adecă trăsuri sîngerate înveregată (86), subsește adecă moare (45), subsire adecă moarte (50), sudorifere adecă ce fac sudoare (90), sufocativă adecă sugrumătoare (63), supurație adecă puroire (78), la supurație adecă la puroire (120), în supurație adecă în puroire (121), apă tepidă adecă călduță (69), terebentină (terpentin) (68), teritoriu (ținut) (114), se termină adecă se sfîrșește (81), titilație (gîdilitură) „titilomanie” (92), transpirația sau răsuflarea vitei contăgioase (21), trucidarea sau uciderea (41), trucidatei adecă ucisei vită (41), să se trucidă adecă să se junghie (80), să se trucide sau să se impuște (91), să-l trucizi adecă să-l omori (112), trupul cel subsit adecă mort (27), urina adecă udul (63), us adecă întrebuințare (46), pășunea vaporoasă sau aburoasă (94), mai vegetă sau mai vioaie (68), veterinari adecă doftorii cei de vite (11), veterinari sau doftori de vite (23), veterinaria adecă măiestria de a doftori vitele (3), măiestria veterinariei adecă a doftoriei de vite (48), (în statul) violenției adecă silniciei (110), să se poată voluta (tăvăli) (82), vomitu adecă borîtu (84).

b) ternare: acrimonia sau tăria, asprirea înrăotățită (95), angina sau brînca sau grumăzarea porcilor (15), antifloghistice adecă asupra focului sau a aprinderei (84), atmosfera adecă ținutul sau cuprinsul aerului celui din stauri (53), cadabrul adecă corpul sau trupul cel mort (87), celeritate (pripire, iuţeală) (63), apă comună (de obște, firească) (61), congestii adecă adunături, strinsuri în cap (81), crustă adecă scoarță sau piele de lard (93), regulele dietetice, adecă ale traiului sau a mîncărei și a beuturei (123), disenteria adecă inima rea, cea putredă (27), disenteria adecă cacăsînge, inima cea rea (51), disposiție (gătire, întocmire) spre turbare „predispoziție” (66), disposiție sau intocmire, gătire (100), grumăzarea sau angina sau brînca porcilor (81), să încrustezi adecă să ungi sau să alipești imflatele picioare ale vitei (80), inflămație (aprindere, obrintitură) (57), se vor îngurgita (ghiftui, împlea) (107), îmflătură pendentă adecă atîrnată, spînzurată (82), depunere metastatică adecă amiscată sau petrecută (77), materia morboasă adecă a morbului sau a boalei (74), periclu sau rişchiu adecă primejdia (74), periferia (împrejurul, partea) (37), cu peripneumenia adecă cu răsuflare grea sau aprinderea plămînilor (57), spre preservativă sau apărare, scutire de vărsat (57), preservativă adecă apărare, scutire adeverită (28), primorilor (celor de frunte sau întîi) (29), apetita prostrată sau depusă, pierdută (63), pulsu sau mişcarea, baterea sîngelui (63), să-i rămoavă adecă să-i lipsească de la sine, să-i lapede „a îndepărta” (106), să se repețească adecă să se adoiască, să se poftorească (sărăturile cele slobozitoare) (68), repețita (adoita, poftorita) (60), resoluția adecă desfacerea, descuiarea ostruțiilor adecă a încuierei (67), separată adecă desfăcută sau despărțită (80), stimulante adecă întăritoare, aromatice (nutremînturi) (108), terminul adecă capetul sau sfîrşitul boalei (88).

c) cuaternare: cautelele adecă luările aminte, apărările, scutirile contagiului (13), îndiferent (lasă-măsă-te-las, nici bun, nici rău, fără ceva mărginire au alegere) (102), melanbonie adecă mîhnire, întristăciune, osteneală a trupului (101), ocură ,apar” (vin, se ivesc, se văd) (64), (chip) preservativ adecă spre apărare, spre ferire, spre scutire (46), o produce sau o naște, o pricinuiaște, o acășsună (62), remit adecă îngăduie, se imblînzesc, alină (68).

d) cvintuple: astremitatelor adecă a marginilor sau a capetelor sau a sfirșiturilor sau a lăturilor „extremitate" (63), nutritoare adecă hrănitoare, intremătoare, intăritoare, amărătoare lături de fărină (50), să se sugrume (să se impedece, să se oprească, să se curme, să se răteze) (106).

Și în cadrul acestora se observă complexitatea structurilor explicative: depunerea, descărcarea materiei ceii morboasă adecă a morbului sau a boalei; devăgînd, adecă imblînd ermii sau pustii pre platei (ulițe); resoluția adecă desfacerea, descuiarea ostruțiilor adecă a încuierei; roborîtoare adecă întăritoare de stomah (de rînză) etc.

Acest tip de glose reprezintă un instrument privilegiat de introducere a noilor termeni; prin interme- 
diul lui sau și adecăa, cititorul este invitat să disocieze între componentele acestor structuri și să interpreteze următorul termen ca pe o explicație a primului termen, împrumutul. Noile cuvinte (inclusiv italienismele și latinismele cu statut de hapax legomena, precum: cautele, moturi, munde, murii, ocură, rămoavă, răsfugări, remotu, spise, subsire, voluta etc.) sînt adaptate sistemului fonetic și morfologic al limbii române și sînt echivalate prin sinonime ori sintagme cunoscute cititorului, glosarea avind, așadar, un scop terminologic; aceste glose urmăresc „transferul terminologic” (Niculescu, 1978, p. 150), raportarea terminologiei culte la una cunoscută lectorului. Intenția cărturarului ardelean este orientată spre „extinderea sferei compartimentului lexical românesc, îmbogățirea inventarului lexical, propunînd limbii și vorbitorului neologisme” (Gafton, 2012, p. 334).

2.2.2. Un alt tip de glosă la care apelează cărturarul ardelean este cea care explică termenul nou (mult mai rar pe cel vechi) printr-o perifrază; asemenea structuri sînt introduse prin adecă, prin expresii de tipul ce/cum se zice/numeşte/cheamă, (cum) se zice românește, care va să zică ori paranteze: dosă adecă deodată cîte o lingură (69), mațul duoden adecă cel de doaosprezece degete de lung (27), epidemică adecă carea se incinge mai preste mult loc întră vitele cele cornute (61), cu epidimie (cu incingere mai preste mult loc) (54), Idiopatică se cheamă dacă aprinderea în unghii färă de a fi fost alta mai nainte boală începe; simptomatică se zice dacă boala de la aprinderea gurei prin depunere metastatică adecă amişcată sau petrecută se naște (77), idrofobia adecă boală carea face a să ingrozi de apă (109), infus adecă băutură ce s-au fiert cu jalie, cu valeriana și cu camfor (52), prin peregrinatori sau nemearnici, adecă prin cei ce îmblă prin țări cu diverse lucruri, negoațe, vestminte de lînă, sau pănură și prin mii alte modruri (21), să se scarifacă adecă cu puţină impunsătură să se pleguiască sau rănească au cu cuțitul să se desfacă (70), (urechile) văcelindu-se adecă într-o parte și într-alta dîndu-se (103), dinții văciliți adecă se mișcă sau, cum se zice, joacă ca mărgeaua „vacilant, mobil” (73), vărsatul cățălat (adecă cînd sgăbunțele sînt boțite, legate laolaltă) (56).

Astfel de glose au eminamente un scop explicativ și informativ; fiind transpuneri interpretative, acestea urmăresc, în spirit iluminist, doar explicarea termenilor, fără să existe, din partea traducătorului, preocuparea de a oferi un lexem terminologic echivalent.

2.2.3. Mai slab reprezentate sînt și glosele care cuprind termeni din alte limbi, latină: aprinderea mațului ce se zice „omas” (23), dosa, latinește „dosis” (47), Lues Omasi, adecă boala mațului celui cărnos (22), acid salis (năcreală de sare) (50), înfuse (infusa) (67), linsătură de gumi de Arabia (mucilago) (69), mațul cel gros ce se zice „omas” (27), mațul ce se zice „abomas” (27), sarea de piatră (sal petre) (65), italiană: arcanu duplicatu (arcano duplicato) (67) sau germană: läzăret (Roth-Stall) (29).

Prezența termenului străin poate reprezenta un indiciu prețios în stabilirea sursei etimologice a cuvîntului românesc.

2.2.4. O altă categorie de glose este reprezentată de cele care includ termeni populari local-regionali, ce se constituie în sinonime diacronice, diatopice sau diastratice (Gafton, 2012, p. 351) și în care autorul face apel la competența lingvistică a cititorului: aborul sau răsuflarea gurei (19), acrescută sau închegată (85), să se adaugă adecă să se mai mărească dosa (99), a amîna adecă a zăbovi (35), amînare adecă zăbavă (36), amînat (tîrziu) (73), amonim (dojenim) (111), amoniți (dojeniţi) (39), arişchioasă adecă primejdioasă (101), boldul sau patima (de cățălit) (110), rane cancroase adecă lupariță (87), case de oaspeți adecă cricime (19), căștiga adecă grija (30), cîrviţă adecă pleșugirea (92), se comîndă adecă se întrebuințează (46), copia adecă turma (6), lîna crispă adecă creață (92), se demînde (poroncească) (29), se dezvînă adecă se slăbește (62), a se dimica (a se bate, a se mînca cu alți cîni) (107), doftorie sau vindecare (98), în foabă adecă în groapă (114), cu friguri putrăde adecă cu lîngoare (57), gînfarea sau îmflarea ugerului (63), halec (hering) (120), (picioarele calului) se întumesc adecă se gînfă (87), larmă sau strigare (115), aer liber (slobod) (45, 65), libre adecă ponți (76), pişatul mistreț adecă puțin (63), mortariu (mojar) (99), mulii sau muşcoii (88), noioase adecă grețoase, scîrbelnice (95), op adecă lipsă $(10,106)$, osedite adecă cuprinse (88), osicrat adecă oțet (74), la ospătărie adecă la cricimă (35), la ospătării sau case de oaspeți adecă cricime (91), pleagă (rană) (69), se pleșugește adecă se

\footnotetext{
${ }^{8}$ Cuvint cunoscut în graiurile transilvănene, cu sensul de „a face comîndul” (pomană, praznic, bunuri adunate pentru înmormîntare).
} 
rărește (16), pricura adecă primejdia (115), în pricură adecă în primejdie (112), mai cu pricură (mai cu primejdie) (64), să se pricure adecă să se primejduiască (113), pricuroasă (primejdioasă) (117), puştlă, adecă ciumă (22), puștlele adecă beșicuțe (55), puștele sau beșicuțe (92), rană sau sgrăbunță (65), rane puturoase, crunte sau, cum se zice, carne vie (78), rișchiu adecă primejdie (104), săponele sau spălături (108), scade adecă se desumflă (78), scăldătoare sau spălarea picioarelor (122), smucide adecă lutoase sau pămînjite (90), stîmpărată adecă călduță (60), stercu (balega) (108), teama sau frica (80), ud sau pişat (19), veglerea adecă privegherea (44), lucrarea vintricelului sau a rînzei (26), păhar de vitru adecă de glajă (54).

Astfel de glose, bazate pe resursele lexicului intern al limbii române, pot releva insuficiențe terminologice ale textului sau ale limbii, ori, dimpotrivă, după cum arată Gafton (2012, p. 350-351), pot arăta faptul că traducătorul dobîndise deprinderea de a mînui acest procedeu în modalități mai complexe: acesta se adresează tuturor românilor, facilitîndu-le accesul la un text scris într-o anumită zonă a teritoriului dacoromân și depășind amprenta regională a materialului lexical.

2.2.5. În alte cazuri, se specifică corespondentele din latină, germană și maghiară ale termenilor populari folosiți: Lîngoarea, carea se cheamă „boală de vite”. Latinește, „Lues Omasi”; ungurește, „Marha Dög” sau „Marha Pestis”; nemțește, „Löser Dürre, Magen-Seuche, Pest-Seuche” (13); Vărsatu de oi. Latinește, "Variole Ovium”, ungurește, "A'Iuhoknak Himlöje”, nemțește, „Die Blattern bez den Schaafen” (13-14); Boala de gură. Latinește, „Lues Oris”, ungurește „Száj-Fájás, Szájgyuladás”, nemțește „Maulsenche: MaulEntzündung” (14); Boala de limbă. Latinește, „Aphte Lingua”, ungurește, „Nyelvenek fenefekélye”, nemțește "Zungen Krebs, Zurgen-Schwemme” (14); Boala de picioare sau de unghii. Latinește, "Lues pedum seu ungularum”, ungurește, „Köröm fájás, sántitás”, nemțește, „Klauen-Seuche” (14); Boala de plămîni. Latinește, „Lues pulmonis”, ungurește, „Tüdögyuladás”, nemțește, „Lungen-Entzündung” (14) etc.

În astfel de glose, termenul neologic nu apare, absența acestuia putînd fi pusă (și) pe seama prudenței cărturarului ardelean de a-l introduce în uzul lingvistic.

2.2.6. O categorie specială de glose este reprezentată de cele șapte rețete redactate în latină (ce conțin formule ale medicamentelor, cantități ale ingredientelor) care, prin intermediul lui adecă, sînt traduse: „[...] să se ungă aftele cu următoriul leac: Rc. Pulv. Absynthii rutæ, scordii aa unc. jj. Spiritus salis acidi drach. jj. Mellis com. q.s. Adecă: cu pulbere de pelin, de rută și de scordiu, din toate cîte doao uncii; din lamura sarei acră, drahme - doao și din miare comună cît e de lipsă sau de ajuns, ca să faci dintru aceste pulberi unsoare. De sînt aftele limbei găngrenoase, această unsoare să întrebuințezi: Rc. Pulv. Cascarillæ, salicis gentianæ, aa unc. jj. Camphor, drach. j. Ungventi ægyptiaci, mel rosarum aa q.s. F. Linimentum, adecă: să iai din pulbere de cascarila și de salce gențiana, dintr-amîndoao cîte doao uncii; de camfor, o drahmă, adecă un cheting; de unsoare de Eghipet, precum și de miare de ruje, dintr-amîndoao atîta cît e de lipsă, spre aceea ca, din toate aceste, să faci unsoare și cu aceea să se ungă găngrenoasele afte” (75-76) etc.

\section{Particularități ale glosării noilor termeni}

Se pot identifica cîteva modalități de explicare, prin glosare, a noilor termeni:

3.1. Glosele traduc unități lexicale care nu se pot descompune: apetita, adecă voia de a mînca (lat. appetitus, germ. Appetit), boale hronice, adecă lung vecuitoare (lat. cronicus, -a, -um), prurit, adecă mîncărime cu scărpinare (lat. pruritus, it. prurito) etc. Aceste traduceri mențin o legătură semantică cu împrumuturile respective, chiar dacă aceasta nu este întotdeauna exactă.

3.2. Glosele traduc unităţi lexicale ce pot fi descompuse în părțile componente: (beuturi) antifloghistice, adecă asupra fierbințelei, circumciderea adecă tăierea împrejur, cu epidimie (cu încingere mai preste mult loc), idrofobia adecă boală carea face a să ingrozi de apă, mațul duoden adecă cel de doaosprezece degete de lung, sudorifere adecă ce fac sudoare etc.

3.3. În multe cazuri, glosele sînt inexacte, stîngace, folosindu-se impropriu anumiţi termeni (din cauza faptului că împrumuturile nu aveau acoperire în lexicul intern); se manifestă, într-un grad mai mare sau mai mic, fenomenul de pierdere a legăturii semantice prin explicarea, în mod diferit, mai mult sau 
mai puțin aproximativ, a sensului termenilor noi ${ }^{9}$ : acrimonia sau ascuţimea, acurata (cu de ajuns); aftele sau răniturile limbei; să se comită adecă să se incredințeze; (sub pedeapsa) confiscației (contraband); să se defalce adecă să se cosască; disenteria adecă inima rea; spre generație adecă spre prăsire; necesitatea adecă lipsa; necesitați sau strimtorați; proporția (potrivirea) etc. În aceste situații, se explică semantic termenii noi, în vederea accesibilizării lor, fără a se crea însă o echivalență semantică precisă. Așadar, echivalențele stabilite prin intermediul gloselor nu sînt întotdeauna exacte, între împrumut și cuvîntul românesc apărînd diferențe de sens: mărci semantice suprimate sau substituite, precum și adaosuri semantice. Multe glose ale aceluiași termen se construiesc prin completări semantice, restrîngeri sau extensiuni de sens, ceea ce arată că, de multe ori, glosarea asigură sensul contextual: acrimonia sau ascuţimea - acrimonia sau tăria, asprirea înrăotățită ; cu afte adecă cu beșicuțe - aftele sau răniturile limbei; antifloghistice adecă asupra focului sau a aprinderei - antifloghistice adecă asupra fierbințtiii; cautele adecă feriri - cautelele adecă luările aminte, apărările, scutirile contagiului; disenteria adecă inima rea, cea putredă - disenteria adecă cacăsînge, inima cea rea; inflamația sau aprinderea - inflämație (aprindere, obrintitură); periclu sau rișchiu adecă primejdia - rişchiu adecă primejdie; preservativ sau scutitoriu asupra pierzătoarei boală - preservativ adecă spre apărare, spreferire, spre scutire; preservativă sau apărare - spre preservativă sau apărare, scutire de vărsat - preservativă adecă apărare, scutire adeverită; prurit adecă mîncătură scărpinătoare - prurit adecă mîncare cu scărpinare; să se scarifacă adecă cu puţină impunsătură să se pleguiască sau rănească au cu cuțitul să se desfacă - să se scarifacă adecă lin să se străpungăa simptome adecă schimbări fără cumpăt - simptomele sau schimbările cele fără cumpăt ale morbului adecă a boalei - simptomele sau schimbările cele necumpătate ale boalei; să se trucidă adecă să se junghie - să se trucide sau să se impuşte - să-l trucizi adecă să-l omori etc.

3.4. Există, în materialul cercetat, numeroase glose în cadrul cărora împrumuturile sînt echivalate prin cuvinte aparținînd limbii comune, cu care se află în raport de sinonimie totală sau parțială; aceste echivalențe sinonimice demonstrează poziția științifică riguroasă pe care se afla cărturarul ardelean: amputația adecă tăierea; astremitatele adecă marginile, capetele, sfîrșiturile, lăturile; aversația adecă urîrea; cadabru adecă trupul cel mort; castrația adecă jugănirea; causa sau pricina; cornute adecă vite cu coarne; custodie (pază); damne adecă pagube; distanță (depărtare); diverse adecă deosebite; se devide sau se împarte; falsă adecă neadevărată; fluid adecă curătoriu; genuin (adevărat); nude adecă goale; ocasia (prilejul); palatul adecă ceriul gurei; remediu (leac); respirația adecă răsuflarea; sapidă (plăcută); scabia adecă rîia; us adecă intrebuințare; veterinari sau doftori de vite etc.

\section{Concluzii}

$\mathrm{Cu}$ un cert caracter didactic, textul evidențiază travaliul explicativ și interpretativ al autorului, care, în procesul de modelare a unui limbaj științific, avea de luptat cu un număr redus de concepte și termeni abstracți; acesta se afla în fața a numeroase și importante probleme de terminologie, ridicate de stadiul în care se afla limba română a perioadei, ce se constituia într-un instrument de lucru imperfect și greoi. Direct preocupat de reformularea mai accesibilă a cunoștințelor, de popularizarea științei, P. Maior reușește totuși să facă un compromis între acuratețea științifică și interesul practic al cititorilor, între limbajul neologic şi cel vechi, popular. Glosa reprezintă pentru acesta un mecanism de inserție în text a împrumuturilor, care sînt echivalate prin sinonime sau structuri cunoscute cititorului. Ponderea însemnată a structurilor explicative evidențiază nevoia de clarificare terminologică, autorul asigurîndu-se că sensul noilor termeni este înțeles de cititor. În cadrul acestora, preponderența covîrșitoare a gloselor lexicale terminologice, de tipul imprumut lexical - cuvînt vechi, arată că scopul principal al învăţatului ardelean este îmbogățirea lexicului literar românesc și crearea unei terminologii științifice culte, o autentică profesiune de credință pe care și-o reafirmă și în postfața lucrării: „Aceasta urmînd, nu numai limpede vei pricepe zisele cuvinte, ci și noao cunoștință de multe cuvinte românești agonisindu-ți, înțelepțtește vei îndemna, aprins de dragostea neamului tău, a îmbogăți dialecta patriei tale, precum toate neamurile Evropei astăzi se nevoiesc nu numai a-și curăți limba sa, a o netezi și a o polii, ci și la acea culme de deplinire a o înălța, cît să o facă de ajuns avută

\footnotetext{
${ }^{9}$ V., în acest sens, și Niculescu (1978, p. 154-155).
} 
spre împărtăşirea tuturor științelor iubitorilor de învățătură oamenilor săi; voind, dorind și suspinînd mama tuturor, natura, ca toți fiii săi, dintră carii pre români mai cu ales talant i-au avuțit și i-au înfrumsățat, cu toată vîrtutea să-și deplinească priceperea și voința spre mărirea lui Dumnezeu, făcătoriului său” (127128). Așadar, utilizarea gloselor urmărește un scop bine precizat: constituirea unui vocabular literar cult, într-o epocă în care se punea stringent problema formării terminologiei științifice în limba română. În cazul gloselor care transpun conceptul printr-o perifrază, net inferioare, ca pondere, celor terminologice, intenția autorului este aceea de a informa, de a explica (acțiune tipică de culturalizare), și nu de a crea un echivalent terminologic în limba română.

\section{Bibliografie}

Cuciureanu, Șt. (1959). Italienisme la Petru Maior, în „Studii și cercetări științifice”, Iași, X, fasc. 1-2, p. 53-67.

Duțu, Al. (1970). Traducere și remodelare în cultura română din perioada Luminilor, în vol. Probleme de literatură comparată și sociologie literară, redactor responsabil: Al. Dima, București, Editura Academiei Romîne.

Gafton, Al. (2012). De la traducere la norma literară, Iași, Editura Universității „Alexandru Ioan Cuza”.

Maior, P. (1813). Istoria besericei românilor, Buda.

Niculescu, Al. (1978). Individualitatea limbii române între limbile romanice. 2. Contribuții socio-culturale, București.

Prodan, D. (1964). Prefața la Gh. Șincai, Învățătură firească spre surparea superștiției norodului, ediție critică și studiu introductiv de D. Ghișe și P. Teodor, prefață de D. Prodan, București, Editura Științifică.

Ursu, N.A. (1961). Cărți de popularizare a științei traduse de Petru Maior, în „Limba română”, X, nr. 2, p. $135-143$.

Ursu, N.A. (1962). Formarea terminologiei științifice românești, București, Editura Științifică.

Ursu, N. A. (2012). Alte două traduceri necunoscute ale lui Petru Maior, în „Limba română”, LXI, nr. 3, p. 413-416. 